\title{
Evaluation of the toxicity of an oil spill conducted through bioassays using the fish Solea senegalensis
}

\author{
Determinación de la toxicidad de un vertido de petróleo \\ mediante el uso de bioensayos con el pez Solea senegalensis
}

\author{
MJ Salamanca ${ }^{1,2 *}$ N Jiménez-Tenorio ${ }^{2,3}$, ML González de Canales ${ }^{3}$, TA DelValls² \\ ${ }^{1}$ Instituto de Ciencias Marinas de Andalucía, CSIC Polígono Río San Pedro s/n, 11510 Puerto Real (Cádiz), Spain. \\ ${ }^{2}$ Cátedra UNESCO/UNITWIN/WiCop, Facultad de Ciencias del Mar y Ambientales, Universidad de Cádiz, Polígono Río San \\ Pedro s/n, 11510 Puerto Real (Cádiz), Spain.*E-mail: maria.salamanca@uca.es \\ ${ }^{3}$ Departamento de Biología, Facultad de Ciencias del Mar y Ambientales, Universidad de Cádiz, Polígono Río San Pedro s/n, \\ 11510 Puerto Real (Cádiz), Spain.
}

\begin{abstract}
The toxicity produced by fuel pollutants was evaluated through bioassays using the Senegalese sole Solea senegalensis. Juveniles were exposed for 21 days to different dilutions obtained by mixing fuel extracted from the Prestige oil tanker and sediment from a clean area of Cádiz Bay. After the exposure period, three biomarkers were analyzed (7-ethoxyresorufin-Odeethylase [EROD], glutathione S-transferase [GST], and glutathione reductase [GR] enzymatic activity), as well as the histopathology of two of the main target organs (gills and liver). Significant $(P<0.05)$ biomarker inductions were observed in the exposed fish analyzed on day 21 relative to the control group (day zero). Lesions were detected in both organs studied, but the liver was the most affected. The frequency of appearance of the lesions was greater in the samples containing higher concentrations of polycyclic aromatic hydrocarbons (PAHs) and metals. The results showed significant correlations between the total PAH concentrations and GST, GR, and EROD enzymatic activity, with correlation coefficients of $R=0.96$ for GST, $R=0.82$ for $\mathrm{GR}$, and $R=0.60$ for EROD.
\end{abstract}

Key words: bioassay, biomarkers, ecotoxicology, fuel, sediment, sole.

\section{Resumen}

Se evaluó la toxicidad que producen los contaminantes presentes en un fuel mediante un bioensayo con el pez plano Solea senegalensis (lenguado). Se expusieron juveniles de esta especie durante 21 días a distintas diluciones realizadas mezclando fuel extraído del buque Prestige y un sedimento procedente de una zona limpia de la Bahía de Cádiz. Tras la exposición se analizaron tres biomarcadores de exposición (actividad enzimática de 7-etoxiresorufin-O-deetilasa [EROD], glutatión S-transferasa [GST] y glutatión reductasa [GR]) junto a la histopatología de dos de los principales órganos diana (branquias e hígado). Los resultados obtenidos mostraron inducciones significativas $(P<0.05)$ en los biomarcadores de exposición analizados en los peces el día 21 respecto del control del día 0 en los peces. Asimismo, se detectaron lesiones en los dos órganos estudiados. El órgano más afectado fue el hígado. La frecuencia de aparición de lesiones fue mayor en las muestras con mayores concentraciones de hidrocarburos aromáticos policíclicos (PAHs, por sus siglas en inglés) y metales. Los resultados obtenidos en este trabajo mostraron correlaciones significativas entre las concentraciones de PAHs totales y la actividad enzimática EROD, GST y GR, obteniéndose coeficientes de correlación de $R=0.60$ para EROD, $R=0.96$ para GST y $R=0.82$ para GR.

Palabras clave: bioensayo, biomarcadores, ecotoxicología, fuel, lenguado, sedimento.

\section{Introduction}

Chronic bioassays, which incorporate more sensitive endpoints than acute bioassays, have become a common tool for the evaluation of sediment quality using numerous biomarkers. For example, the induction of cytochrome P450 isoenzymes is an adaptive response that can be used in several species as an early warning of contamination. Hence, 7-ethoxyresorufin-Odeethylase (EROD) enzymatic activity was chosen as an exposure biomarker for this study. Two other enzymes from the different phases of detoxification whose activity is altered in

\section{Introducción}

Los bioensayos crónicos, que incorporan respuestas más sensibles que los agudos, se han convertido en una herramienta común para realizar evaluaciones de la calidad de sedimento mediante numerosos biomarcadores. Por ejemplo, la inducción de isoenzimas del citocromo P450 es una respuesta adaptativa que puede utilizarse en muchas especies como alerta temprana de contaminación, por lo que en este estudio se eligió la actividad enzimática 7-etoxiresorufin-O-deetilasa (EROD) como biomarcador de exposición. Se evaluaron también otras 
the presence of organic pollutants were also evaluated, namely glutathione S-transferase (GST) and glutathione reductase (GR). EROD enzymatic activity is a defense mechanism in the first phase of the detoxification metabolism that estimates the induction of cytochrome P4501A (Reynolds et al. 2003) and whose increase has been observed in several fish species after exposure to organic pollutants, including polycyclic aromatic hydrocarbons (PAHs) (Van der Ost et al. 2003). GST is an enzyme from the second phase of detoxification, and even though its role in the exposure to organic pollutants is not as clear as that of EROD activity, it has been found to be an effective defense mechanism against oxidative damage and peroxidation products (George 1994). GR is an oxidative stress enzyme that intervenes in the homeostasis of the levels of reduced and oxidized glutathione under oxidative stress conditions (Winston and Di Giulio 1991), and its induction in fish exposed to organic pollutants has been recorded in numerous studies (Van der Ost et al. 2003).

The ability of many pollutants to alter different cells, tissues or organs has resulted in the use of histopathological techniques to evaluate the effects of contamination (DelValls 1999, Riba et al. 2005). Histopathology has become a valid tool in the study of the biological effects of environmental pollution, allowing the detection and characterization of the effects of exposure to toxic and carcinogenic substances (Reynolds et al. 2003). Numerous studies dealing with accidental oil spills have been conducted under laboratory and field conditions (MariñoBalsa et al. 2003, Evangelista et al. 2005, Fernández et al. 2006b, Morales-Caselles et al. 2007), but little research has been done with vertebrates that includes the induction of exposure biomarkers and histopathological damage after long-term exposure to different concentrations of fuel. In this study, juveniles of a commercial species, Solea senegalensis, were used to evaluate the toxicity of PAHs and other pollutants found in fuel under laboratory conditions using a solid-phase bioassay. The organisms were exposed for 21 days to different dilutions of fuel from the Prestige oil tanker, which mas mixed with sediment collected from a clean area of Cádiz Bay, Spain (Riba et al. 2004). The measurement parameters studied were three exposure biomarkers (EROD, GST, and GR activity) and histological damage in the gills and liver, in order to evaluate their response in a flatfish after exposure to different concentrations of fuel.

\section{Material and methods}

\section{Toxicity test}

Fuel from the Prestige tanker was mixed with control sediment from a clean area, at concentrations of $0.5 \%, 2 \%, 8 \%$, and $16 \%$. A negative control contained only sediment. The control sediment selected for the experiment was sandy, with $2.01 \%$ of fine grains $(<0.063 \mathrm{~mm})$ and $1.07 \%$ of total organic carbon content, both calculated based on dry weight. The sediment was collected from a clean area of Cádiz Bay (Riba et al. enzimas de las distintas fases de detoxificación (glutatión Stransferasa (GST) y glutatión reductasa (GR)) cuya actividad se ve alterada en presencia de contaminantes orgánicos. La actividad enzimática EROD es un mecanismo de defensa de la primera fase del metabolismo de detoxificación que estima la inducción del citocromo P4501A (Reynolds et al. 2003) y cuyo incremento ha sido observado en numerosas especies de peces después de ser expuestos a contaminantes orgánicos, incluyendo los hidrocarburos aromáticos policíclicos (PAHs) (Van der Ost et al. 2003). La GST es una enzima de la segunda fase de detoxificación que, aunque no tiene un papel tan claro en la exposición de contaminantes orgánicos como la actividad EROD, se ha demostrado que es un mecanismo de defensa efectivo contra el daño oxidativo y los productos peroxidativos (George 1994). La GR es una enzima de estrés oxidativo que interviene en la homeostasis de los niveles de glutatión reducido y oxidado en condiciones de estrés oxidativo (Winston y Di Giulio 1991) y cuya inducción se ha observado en peces expuestos a contaminantes orgánicos en numerosos estudios (Van der Ost et al. 2003).

La capacidad de muchos contaminantes de alterar diferentes células, tejidos u órganos ha dado lugar al empleo de técnicas histopatológicas para evaluar los efectos de la contaminación (DelValls 1999, Riba et al. 2005). La histopatología se convierte así en una herramienta válida para el estudio del efecto biológico de los contaminantes en el medioambiente ya que es capaz de detectar y caracterizar los efectos de la exposición a sustancias tóxicas y carcinogénicas (Reynolds et al. 2003). En este trabajo se usaron juveniles de una especie comercial, Solea senegalensis, para evaluar la toxicidad de los PAHs y otros contaminantes presentes en un fuel en condiciones de laboratorio con un bioensayo en fase sólida. Existen numerosos trabajos (Mariño-Balsa et al. 2003, Evangelista et al. 2005, Fernández et al. 2006b, Morales-Caselles et al. 2007), realizados bajo condiciones de laboratorio y de campo, relacionados con vertidos accidentales de petróleo; sin embargo, se han realizado muy pocos estudios con vertebrados que incluyan inducción de biomarcadores de exposición y daño histopatológico tras una exposición de larga duración a distintas concentraciones de fuel. En este estudio los organismos fueron expuestos durante 21 días a diferentes diluciones de fuel del buque Prestige, realizadas mezclando éste con sedimento recogido en una zona limpia de la Bahía de Cádiz (Riba et al. 2004). Los parámetros de medida que se estudiaron fueron tres biomarcadores de exposición (actividad EROD, GST y GR) y daño histológico en branquias e hígado, con el fin de evaluar sus respuestas en un pez plano tras la exposición a distintas proporciones de fuel.

\section{Material y métodos}

\section{Test de toxicidad}

Se mezcló fuel extraído del buque Prestige con sedimento control procedente de una zona limpia a concentraciones de 
2004), stored in hermetically-sealed, sterile plastic containers, and refrigerated until arrival at the laboratory. Once there, the sediment was sifted through a $0.5-\mathrm{mm}$ sieve and stored at $4^{\circ} \mathrm{C}$, in the dark, until its use in the bioassay, within 14 days of its collection. The dilutions were prepared by mixing the amounts of fuel and clean sediment needed for each concentration $(0.5 \%, 2 \%, 8 \%$, and $16 \%)$. The determinations were made on a dry-weight basis, calculating the sediment percent moisture content from three subsamples that were allowed to dry at ambient temperature (approximately $23^{\circ} \mathrm{C}$ ) and considering the fuel moisture, which was $25 \%$. The sediment was first weighed and deposited in the tanks used for the experiment. The amount of fuel needed in each case was then added over the sediment. The dilutions were chosen based on the composition of the fuel, which was known at the time of designing the experiment, in order to obtain the concentrations of PAHs and other fuel pollutants similar to those found in natural sediments affected by the black tide (Fernández et al. 2006a, Morales-Caselles 2006a, b).

Solea senegalensis juveniles of $125 \mathrm{~g}$ mean weight were selected. The specimens were obtained from a marine culture facility and transported to the laboratory where they were acclimatized for two weeks prior to initiating the experiment. For the bioassay, we used a system of $25-\mathrm{L}$, closed circuit tanks, with continuous aeration. The tanks contained the fuelsediment mixture and seawater at a 1:4 (v/v) ratio. Each dilution was made in triplicate and 10 individuals were placed in each tank. Salinity $(35 \pm 2)$, temperature $\left(19 \pm 2^{\circ} \mathrm{C}\right), \mathrm{pH}$ (8.0-8.5), dissolved oxygen ( $>80 \%$ saturation), and ammonium $\left(<0.001 \mathrm{mg} \mathrm{L}^{-1}\right)$ were controlled to ensure suitable levels for the bioassay. A natural photoperiod was used (14:10, for the southern Iberian Peninsula in late spring). The individuals were fed daily ("Mar Perla T", aproximately $0.2 \mathrm{~g}$ per fish). Renewal of $33 \%$ of the tank water was done once or twice a week, using peristaltic pumps, to maintain the quality standards.

\section{Biomarkers measured}

After 21 days of exposure, six individuals were collected from each dilution for the measurement of the exposure biomarkers in the liver (EROD, GST, and GR) and of the effect biomarkers (histological alterations in gills and liver). Samples were also taken at the beginning of the experiment (day zero) to be used as control. Specimens were anesthetized with 2-phenoxyethanol $(0.1 \%)$ prior to dissection.

The liver extracted during each dissection was divided into two for the biomarker and histopathologic evaluations. The samples destined for the biomarker measurements were preserved at $-80^{\circ} \mathrm{C}$ until their analysis. The samples were homogenized in a Tris-acetate buffer before their analysis, following the method described by Lafontaine et al. (2000). They were then centrifuged at $10,000 \mathrm{~g}$ for $30 \mathrm{~min}$ at a temperature of $4^{\circ} \mathrm{C}$ for the extraction of the cytosolic phase. In addition to the previously mentioned biomarkers, the total protein content
$0.5 \%, 2 \%, 8 \%$ y $16 \%$ y un control negativo que sólo contenía sedimento (Ca). El sedimento control seleccionado fue de tipo arenoso, con $2.01 \%$ de finos $(<0.063 \mathrm{~mm})$ y un contenido en carbono orgánico total de $1.07 \%$, ambos calculados sobre peso seco. El sedimento se recolectó en una zona limpia de la Bahía de Cádiz (Riba et al. 2004) y se almacenó en recipientes de plástico estériles, herméticamente cerrados y refrigerados hasta su llegada a laboratorio. Una vez allí, el sedimento se tamizó a $0.5 \mathrm{~mm}$ y se almacenó a $4^{\circ} \mathrm{C}$ de temperatura, en oscuridad, hasta su uso en el bioensayo, nunca más de 14 días después de su recogida. Las diluciones se prepararon mezclando las cantidades de fuel y sedimento limpio necesarias para lograr cada porcentaje $(0.5 \%, 2 \%, 8 \%$ y $16 \%)$. Los cálculos se hicieron sobre peso seco, por lo que se calculó el porcentaje de humedad del sedimento a partir de tres submuestras que se dejaron secar a temperatura ambiente $\left(23^{\circ} \mathrm{C}\right.$ aproximadamente), teniendo en cuenta la humedad del fuel, que era del $25 \%$. En primer lugar se pesó el sedimento y se depositó en los acuarios donde se realizó el experimento. A continuación, se añadió la cantidad de fuel necesaria en cada caso sobre el sedimento. Las diluciones se eligieron en base a la composición del fuel, conocida en el momento del diseño del experimento, con el fin de conseguir concentraciones de PAHs y otros contaminantes del fuel similares a las encontradas en sedimentos naturales afectados por la marea negra (Fernández et al. 2006a, MoralesCaselles 2006a, b).

Se seleccionaron juveniles de $S$. senegalensis con un peso medio de $125 \mathrm{~g}$. Los ejemplares procedían de una planta de cultivos marinos y fueron transportados hasta el laboratorio para su aclimatación durante dos semanas antes del comienzo del experimento. Para el bioensayo se utilizó un sistema de acuarios de $25 \mathrm{~L}$ en circuito cerrado, con aireación continua, que contenían la mezcla fuel-sedimento y agua de mar en una proporción 1:4 (v/v). Cada dilución se realizó por triplicado y en cada acuario se dispusieron 10 individuos. Se controlaron los valores de salinidad $(35 \pm 2)$, temperatura $\left(19 \pm 2^{\circ} \mathrm{C}\right), \mathrm{pH}$ (8.0-8.5), oxígeno disuelto ( $>80 \%$ de saturación) y amonio $\left(<0.001 \mathrm{mg} \mathrm{L}^{-1}\right)$ para asegurar que éstos se encontraban en los niveles adecuados para la realización del bioensayo. El fotoperiodo fue el natural (14:10, para el sur de la Península Ibérica a finales de primavera). Los individuos fueron alimentados diariamente con pienso (aproximadamente $0.2 \mathrm{~g}$ por pez) "Mar Perla T". La renovación del $33 \%$ del agua de los tanques se realizó mediante bombas peristálticas, una o dos veces por semana, para mantener los patrones de calidad.

\section{Biomarcadores medidos}

El día 21 de exposición se recogieron seis individuos en cada una de las distintas diluciones para la medición de los biomarcadores de exposición en hígado (EROD, GST y GR) y los biomarcadores de efecto (alteraciones histológicas en branquias e hígado). Al comienzo del experimento también se tomaron muestras para usarlas como control (día cero). Los 
of each sample was also determined in order to normalize the data obtained. The concentration of proteins was evaluated according to the method described by Bradford (1976), using bovine serum albumin (Sigma Aldrich) as standard.

The protocol described by Gagné and Blaise (1993) was used to measure EROD enzymatic activity. The results obtained were normalized based on the total protein content,

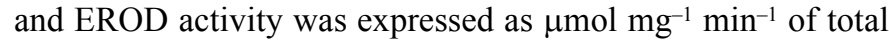
proteins. The GST and GR enzymes were analyzed following the protocols described by Martín-Díaz et al. (2004a, b; 2005).

To analyze the histopathologic damage, samples from the target organs were fixed in formol $(10 \%)$ buffered with $0.1 \mathrm{M}$ phosphate ( $\mathrm{pH}$ 7.2) and mounted on paraffin blocks for the preparation of the $6-8-\mu \mathrm{m}$-thick histological sections. The histological sections were stained with Harris hematoxylin and eosin, and Harris hematoxylin and VOF (Gutiérrez 1967), and observed under a microscope. The histopathological alterations were semiquantitatively evaluated in the specimens exposed to the different dilutions based on the frequency of appearance of lesions in a total of six individuals from each dilution (Jiménez-Tenorio et al. 2007). The general indices of lesions in gills (IGG) and liver (IGL) were calculated.

\section{Chemical analyses}

Samples for the chemical analyses were taken at the beginning of the experiment. The PAHs analyzed in the sediment and fuel mixtures were the $\Sigma 16 \mathrm{PAHs}$ recommended by the US Environmental Protection Agency (Keith and Telliard 1979). Briefly, an extraction of the dry sample was produced using a hexane/acetone mixture in a microwave oven, then replacing the solvent with hexane and, finally, concentrating the sample. Purification through alumina then followed and the concentration of PAHs was determined by CG/MS. The NRC-CNRC HS-6 reference material was used to verify the analytical procedure. The results are given in $\mathrm{mg} \mathrm{kg}^{-1}$ dry weight.

To determine trace metals ( $\mathrm{Ni}, \mathrm{V}, \mathrm{Cd}, \mathrm{Pb}, \mathrm{Cr}, \mathrm{Co})$, the sediments were digested as described by Loring and Rantala (1992), and quantified by graphite furnace atomic absorption spectrometry (Perkin-Elmer $4100 \mathrm{ZL}$ ) (Cobelo-García et al. 2005). The results are given in $\mathrm{mg} \mathrm{kg}^{-1}$ dry weight. The analytical procedure was verified using MESS-1 NRC and CRM 277 BCR reference material. All the results showed confidence values of $90-110 \%$.

\section{Statistical analyses}

All statistical analyses were performed using SPSS 15.0 software. The normality and homocedasticity of the data were checked using the Kolmogorov-Smirnov and Levene tests. Analysis of variance was applied to evaluate the differences between the values of the different biomarkers in the controls and in the different dilutions. The Pearson matrix was used to determine the correlation between the concentrations of the pollutants and the biomarkers measured. ejemplares fueron anestesiados con 2-fenoxietanol al $0.1 \%$ antes de su disección.

Los hígados extraídos en cada disección fueron divididos en dos para determinar biomarcadores de exposición e histopatologías. Las muestras destinadas a la medida de biomarcadores fueron conservadas a $-80^{\circ} \mathrm{C}$ hasta su análisis. Las muestras fueron homogenizadas con un tampón Tris-acetato antes de su análisis, siguiendo la metodología descrita por Lafontaine et al. (2000); posteriormente fueron centrifugadas a $10000 \mathrm{~g}$ durante 30 min y a una temperatura de $4^{\circ} \mathrm{C}$ para la extracción de la fase citosólica. Además de los biomarcadores de exposición nombrados anteriormente, se midieron los contenidos de proteínas totales de cada muestra, con el fin de normalizar los datos obtenidos. La concentración de proteínas fue evaluada utilizando el método descrito por Bradford (1976) utilizando albúnima de suero bovino (Sigma Aldrich) como estándar.

La actividad enzimática EROD se midió siguiendo el protocolo descrito por Gagné y Blaise (1993). Los resultados obtenidos se normalizaron frente a la concentración de proteínas

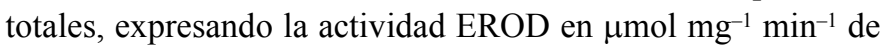
proteínas totales. Las enzimas GST y GR se analizaron siguiendo los protocolos descritos por Martín-Díaz et al. (2004a, b; 2005).

Para el análisis del daño histopatológico, las muestras de órganos diana se fijaron en formol al 10\% tamponado con fosfato $0.1 \mathrm{M}$ (pH 7.2) y se montaron en bloques de parafina, para realizar cortes histológicos de 6 a $8 \mu \mathrm{m}$ de grosor. Los cortes histológicos se tiñeron con hematoxilina de Harris-eosina y hematoxilina de Harris-VOF (Gutiérrez 1967) y se observaron al microscopio para su estudio histopatológico. Las alteraciones histopatológicas fueron evaluadas semicuantitativamente en los peces expuestos a las diferentes diluciones usando la frecuencia de aparición de la lesión en un total de seis individuos en cada dilución (Jiménez-Tenorio et al. 2007). Se calcularon los índices generales de lesión en branquias (IGG) y en hígado (IGL).

\section{Análisis químicos}

Al comienzo del experimento se tomaron muestras para los análisis químicos. En las mezclas de sedimento y fuel se analizaron los $516 \mathrm{PAHs}$ recomendados por la Agencia de Protección Ambiental de los EUA (Keith y Telliard 1979). Resumidamente, la muestra seca fue sujeta a extracción con una mezcla de hexano/acetona en horno microondas, después se cambió el solvente por hexano y se concentró la muestra. Posteriormente la muestra resultante se purificó con alúmina y finalmente se determinó su concentración de PAHs mediante CG/MS, usando material de referencia NRC-CNRC HS-6 para comprobar el procedimiento analítico. Los resultados se expresaron en $\mathrm{mg} \mathrm{kg}^{-1}$ de peso seco.

Para evaluar los metales traza (Ni, V, Cd, $\mathrm{Pb}, \mathrm{Cr}, \mathrm{Co})$, los sedimentos fueron digeridos como describen Loring y Rantala 


\section{Results}

The results of the pollutants (total and individual PAHs and trace metals, in $\mathrm{mg} \mathrm{kg}^{-1}$ dry weight) measured in the fuel dilutions $(0.5 \%, 2 \%, 8 \%$, and $16 \%)$ and control sediment $(\mathrm{Ca})$ are summarized in table 1 . In the negative control, PAH concentrations were not detected $\left(0.1 \mu \mathrm{g} \mathrm{kg}^{-1}\right.$ detection limit), so the PAH content in the dilutions can be attributed to the fuel, while the heavy metal concentrations were well below the guideline values to which they were compared (DelValls et al. 2004).

In general, both the exposure biomarkers and histopathological damage analyzed indicated significant induction $(P<$ 0.05 ) relative to the negative control, tending to increase as the fuel concentration increased (fig. 1). Table 2 shows the results obtained for enzymatic activity (EROD, GST, and GR) and the lesion indices calculated based on the semiquantitative evaluation of the frequency of appearance of lesions in the gills and liver. The organisms analyzed on day zero did not show any histopathological damage and functioned as control organisms. The lesions most frequently observed in the gills were desquamation of secondary lamellar epithelial cells, hypertrophy and hyperplasia, blood extravasation in secondary lamellae, and shortening of secondary lamellae (fig. 2a). The lesions most frequently observed in the liver were the alteration and vacuolization of hepatocytes (fig. 2b).

The Pearson matrix showed significant correlations for the PAH concentrations and exposure biomarkers (table 3). Total PAH concentrations were correlated with EROD, GST, and GR enzymatic activity and the following correlation coefficients were obtained: $R=0.60$ for EROD (significant at a level of $0.05), R=0.96$ for GST $(P<0.05)$, and $R=0.82$ for GR (significant at a level of 0.01 ). The mortality recorded throughout the experiment ranged from $30 \%$ for the $0.5 \%$ dilution to $50 \%$ for the $16 \%$ dilution.

\section{Discussion}

The predominant individual PAHs in fuel are pyrene (461 mg kg-1), phenanthrene (347.5 mg kg-1), naphthalene (317 mg kg-1), chrysene (93.5 mg kg-1), fluorene (114.6 mg $\left.\mathrm{kg}^{-1}\right)$, and acenaphthene $\left(59.3 \mathrm{mg} \mathrm{kg}^{-1}\right)$. The high molecular weight PAHs tend to remain associated with the sediment (Mariño-Balsa et al. 2003), whereas the low molecular weight PAHs (2-4 rings), predominant in the fuel analyzed herein, present more acute toxicity because of greater solubility (Fernández et al. 2006a, b). It would therefore be expected that a fraction of the fuel PAHs would pass to the aqueous phase, producing the toxicity observed. Albaigés and Bayona (2003) found that naphthalene can accumulate in the biota and that concentrations in sediments higher than $34.6 \mathrm{mg} \mathrm{kg}^{-1}$ (dry weight) can have negative effects on benthic organisms. Anthracene, fluoranthene, and pyrene showed acute toxicity in marine invertebrate embryos and larvae (Pelletier et al. 1997, 2000). In general, exposure to high concentrations of PAHs is harmful to the exposed organisms who can bioaccumulate
(1992) y se cuantificaron por espectrometría de absorción atómica de grafito (Perkin-Elmer $4100 \mathrm{ZL}$ ) (Cobelo-García et al. 2005). Los resultados se expresaron en $\mathrm{mg} \mathrm{kg}^{-1}$ de peso seco. El procedimiento analítico fue comprobado usando material de referencia MESS-1 NRC y CRM 277 BCR. Todos los resultados mostraron valores de confianza entre $90 \%$ y $110 \%$.

\section{Análisis estadístico de los datos}

Los análisis estadísticos se realizaron con el software SPSS 15.0. Se aplicaron las pruebas de Kolmogorov-Smirnov y de Levene para comprobar la normalidad y la homocedasticidad de los datos. Se aplicó un análisis de varianza (ANOVA) para evaluar las diferencias entre los valores de los distintos biomarcadores en los controles y en las diferentes diluciones. Se utilizó la matriz de Pearson para determinar la correlación entre las concentraciones de contaminantes y los biomarcadores medidos.

\section{Resultados}

La tabla 1 muestra los resultados resumidos para los contaminantes (PAHs totales e individuales y metales traza expresados en $\mathrm{mg} \mathrm{kg}^{-1}$ de peso seco) que fueron calculados en las diluciones de fuel $(0.5 \%, 2 \%, 8 \%$ y $16 \%)$ y el sedimento control (Ca). En el control negativo no se detectaron concentraciones de PAHs (límite de detección $0.1 \mu \mathrm{g} \mathrm{kg}^{-1}$ ), por lo que el contenido de PAHs en las diluciones depende únicamente del fuel, mientras que la concentración de metales pesados se encontró muy por debajo de los valores guías con los que fueron comparados (DelValls et al. 2004).

En general, los biomarcadores de exposición, así como los daños histopatológicos analizados, mostraron una inducción significativa $(P<0.05)$ respecto al control negativo, con una tendencia creciente conforme aumenta la concentración de fuel (fig. 1). La tabla 2 muestra los resultados obtenidos para la actividad enzimática (EROD, GST y GR) y los índices de lesión calculados a partir de la evaluación semicuantitativa de la frecuencia de aparición de lesiones en hígado y branquias. Los organismos analizados el día cero no presentaron en ningún caso daños histopatológicos y fueron tomados como organismos control. Las lesiones más frecuentes observadas en branquias fueron la descamación de las células epiteliales de las laminillas secundarias, hipertrofia e hiperplasia, extravasación sanguínea en las laminillas secundarias y acortamientos en dichas laminillas (fig. 2a). Las lesiones más frecuentes observadas en hígado son la alteración y vacuolización de los hepatocitos (fig. 2b).

La matriz de correlación de Pearson mostró correlaciones significativas entre las concentraciones de PAHs y los biomarcadores de exposición (tabla 3). Se correlacionaron las concentraciones de PAHs totales con la actividad enzimática EROD, GST y GR, obteniéndose coeficientes de correlación $R=0.60$ 
Table 1. Concentrations of individual and total PAHs and metals, in $\mathrm{mg} \mathrm{kg}^{-1}$ dry weight, measured in the negative control sediment (Ca), the pure fuel, and each dilution ( $\mathrm{n} . \mathrm{d}$. = below the detection limit, $<0.1 \mu \mathrm{g} \mathrm{kg}^{-1}$ ).

Tabla 1. Concentraciones de PAHs individuales, totales y metales, en $\mathrm{mg} \mathrm{kg}^{-1}$ de peso seco, calculadas para el sedimento control negativo (Ca), el fuel puro y cada dilución de fuel en sedimento (n.d. = por debajo del límite de detección, $<0.1 \mu \mathrm{g} \mathrm{kg}^{-1}$ ).

\begin{tabular}{|c|c|c|c|c|c|c|c|}
\hline & & Oil & $\mathrm{Ca}$ & $0.5 \%$ & $2 \%$ & $8 \%$ & $16 \%$ \\
\hline \multirow[t]{17}{*}{ PAHs } & Fluorene & 114.6 & n.d. & 0.57 & 2.29 & 9.17 & 18.34 \\
\hline & Naphthalene & 317.0 & n.d. & 1.59 & 6.34 & 25.36 & 50.20 \\
\hline & Phenanthrene & 347.5 & n.d. & 1.74 & 6.95 & 27.80 & 55.60 \\
\hline & Acenaphthene & 59.3 & n.d. & 0.30 & 1.19 & 4.74 & 9.49 \\
\hline & Anthracene & 48.4 & n.d. & 0.24 & 0.97 & 3.87 & 7.74 \\
\hline & Fluoranthene & 42.2 & n.d. & 0.21 & 0.84 & 3.38 & 6.75 \\
\hline & Pyrene & 461.0 & n.d. & 2.31 & 9.22 & 36.88 & 73.76 \\
\hline & Benzo[a]anthracene & 44.9 & n.d. & 0.22 & 0.90 & 3.59 & 7.18 \\
\hline & Chrysene & 93.5 & n.d. & 0.47 & 1.87 & 7.48 & 14.96 \\
\hline & Benzofluoranthene & 16.0 & n.d. & 0.08 & 0.32 & 1.28 & 2.56 \\
\hline & Benzo[e]pyrene & 45.7 & n.d. & 0.23 & 0.91 & 3.66 & 7.31 \\
\hline & Benzo[a]pyrene & 24.7 & n.d. & 0.12 & 0.49 & 1.98 & 3.95 \\
\hline & Perilene & 11.4 & n.d. & 0.06 & 0.23 & 0.91 & 1.82 \\
\hline & Dibenzo[ah]anthracene & 5.7 & n.d. & 0.03 & 0.11 & 0.46 & 0.91 \\
\hline & Benzo[ghi]perilene & 17.1 & n.d. & 0.09 & 0.34 & 1.37 & 2.74 \\
\hline & Indene[123-cd]pyrene & 5.7 & n.d. & 0.03 & 0.11 & 0.46 & 0.91 \\
\hline & Total PAHs & 1654.0 & n.d. & 8.27 & 33.08 & 132.30 & 264.60 \\
\hline \multirow[t]{6}{*}{ Metals } & $\mathrm{Cu}$ & 6.28 & 7.00 & 6.98 & 6.97 & 6.92 & 6.87 \\
\hline & $\mathrm{Cd}$ & 0.19 & 0.95 & 0.92 & 0.91 & 0.86 & 0.80 \\
\hline & $\mathrm{Pb}$ & 0.55 & 2.30 & 2.27 & 2.25 & 2.14 & 2.00 \\
\hline & $\mathrm{Zn}$ & 13.70 & 21.50 & 21.26 & 21.15 & 20.69 & 20.08 \\
\hline & $\mathrm{Cr}$ & 0.31 & 0.12 & 0.10 & 0.10 & 0.12 & 0.13 \\
\hline & $\mathrm{Ni}$ & 0.55 & 0.06 & 0.06 & 0.07 & 0.10 & 0.14 \\
\hline
\end{tabular}

these pollutants in their tissues (Laffon et al. 2006, SorianoSanz et al. 2006).

Regarding the histopathology, the lesion indices calculated were not as high as in other studies using fish to evaluate natural sediments (Jiménez-Tenorio et al. 2007, Morales-Caselles et al. 2007), since most mortality occurred due to direct contact of the gills with the fuel and not through the lesions. Nevertheless, the liver alterations observed were similar to those found in studies on different fish species sampled in the area affected by the Prestige oil spill (Marigómez et al. 2006).

The enzymatic activity evaluated in $S$. senegalensis showed a significant increase relative to the controls. Increased activity of the three enzymes studied herein has been observed in different fish, crustacean, and bivalve species exposed to PAHs and PCBs (Van de Oost et al. 2003, Martín-Díaz 2004). Similar results were also obtained by Martínez-Gómez et al. (2006) for the fish Lepidorhombus boscii and Callionymus lyra.

This study confirms the toxic nature of the fuel spilled by the Prestige, which clearly affected S. senegalensis as shown by the results obtained for the biomarkers analyzed and the para EROD (significativo a nivel de 0.05 ), $R=0.96$ para GST $(P<0.05)$ y $R=0.82$ para GR (significativo a nivel de 0.01 ). La mortalidad registrada a lo largo del experimento osciló entre un $30 \%$ para la dilución más pequeña $(0.5 \%)$ y $50 \%$ para la dilución del 16\%.

\section{Discusión}

Los PAHs individuales predominantes en el fuel son pireno (461 mg kg-1), fenantreno (347.5 mg kg-1), naftaleno (317 mg $\mathrm{kg}^{-1}$ ), criseno (93.5 $\mathrm{mg} \mathrm{kg}^{-1}$ ), fluoreno (114.6 $\mathrm{mg} \mathrm{kg}^{-1}$ ) y acenafteno (59.3 $\mathrm{mg} \mathrm{kg}^{-1}$ ). Los PAHs de mayor peso molecular tienden a permanecer asociados al sedimento (Mariño-Balsa et al. 2003), mientras que los PAHs de bajo peso molecular (2-4 anillos), predominantes en el fuel de este trabajo, presentan una mayor toxicidad aguda debido a su mayor solubilidad (Fernández et al. 2006a, b). Cabe esperar entonces que una fracción de los PAHs del fuel fuera pasando a la fase acuosa, produciendo la toxicidad observada. Estudios previos realizados por Albaigés y Bayona (2003) revelaron que el naftaleno 

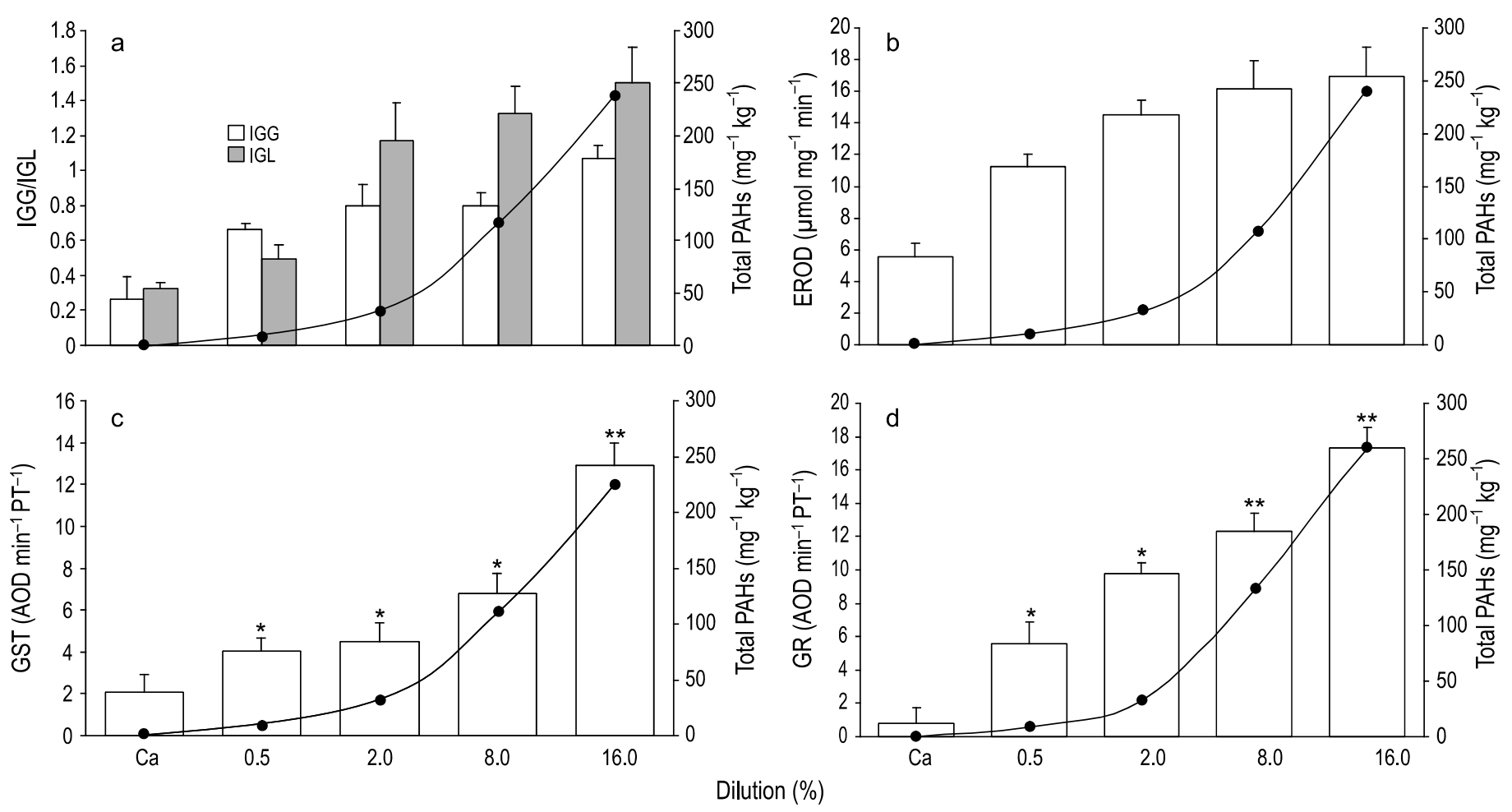

Figure 1. (a) General indices of lesions in gills (IGG) and liver (IGL), and (b, c, d) enzymatic activity of 7-ethoxyresorufin-O-deethylase (EROD), glutathione Stransferase (GST), and glutathione reductase (GR), used as exposure biomarkers (bars), and total PAH concentration (curves) for each dilution. Asterisks indicate significant differences between the biomarkers analyzed in the exposed and control organisms (** $\left.P<0.01,{ }^{\star} P<0.05\right)$. The standard deviation over the mean is indicated with vertical lines.

Figura 1. (a) Indices de lesión en branquias (IGG) e hígado (IGL), y (b, c, d) actividades enzimáticas de la 7-etoxiresorufin-O-deetilasa (EROD), glutatión Stransferasa (GST) y glutatión reductasa (GR), usadas como biomarcadores de exposición (barras), frente a la concentración total de PAHs (curvas) para cada dilución. Los asteriscos indican diferencias significativas entre los biomarcadores analizados en los organismos expuestos y el control (** $P<0.01,{ }^{*} P<0.05$ ), mientras que la desviación estándar sobre la media se señala con las líneas verticales.

histopthological alterations. It is clear that high concentrations of hydrocarbons not only affect small-sized organisms, such as amphipods (Morales-Caselles et al. 2006b), or the success of emrbyogenesis in different aquatic organisms, such as echinoderms (Fernández et al. 2006a, b) and bivalves (Mariño-Balsa et al. 2003), but that they also produce negative effects on puede acumularse en la biota y que concentraciones de naftaleno en sedimento superiores a $34.6 \mathrm{mg} \mathrm{kg}^{-1}$ (en peso seco) pueden producir efectos negativos en los organismos bentónicos. El antraceno, fluoranteno y pireno mostraron toxicidad aguda en larvas y embriones de invertebrados marinos (Pelletier et al. 1997, 2000). En general, la exposición a altas

Table 2. Summary of the lesion indices calculated for gills (IGG) and liver (IGL) after the period of exposure. Also shown are the results of the increase in enzymatic activity of the exposure biomarkers measured relative to a control group of unexposed individuals (Ca).

Tabla 2. Resumen de los índices de lesión calculados en branquias (IGG) e hígados (IGL) después del periodo de exposición. Se incluyen también los resultados del incremento de la actividad enzimática de los biomarcadores de exposición medidos respecto de un grupo control de individuos que no fueron expuestos.

\begin{tabular}{|c|c|c|c|c|c|c|}
\hline & & $\mathrm{Ca}$ & $0.5 \%$ & $2 \%$ & $8 \%$ & $16 \%$ \\
\hline \multirow[t]{2}{*}{ Histopathology } & IGG & 0.27 & 0.67 & 0.80 & 0.80 & 1.07 \\
\hline & IGL & 0.33 & 0.50 & 1.17 & 1.33 & 1.50 \\
\hline \multirow[t]{3}{*}{ Exposure biomarkers } & $\begin{array}{l}\text { EROD } \\
\mu \mathrm{mol} \mathrm{mgPT}-1 \mathrm{~min}^{-1}\end{array}$ & 5.545 & 11.281 & 14.500 & 16.170 & 16.934 \\
\hline & $\begin{array}{l}\text { GST } \\
\text { AOD } \min ^{-1} \mathrm{PT}^{-1}\end{array}$ & 2.054 & 4.044 & 4.477 & 6.781 & 12.885 \\
\hline & $\begin{array}{l}\mathrm{GR} \\
\mathrm{AOD} \min ^{-1} \mathrm{PT}^{-1}\end{array}$ & 0.819 & 5.545 & 9.750 & 12.320 & 17.335 \\
\hline
\end{tabular}



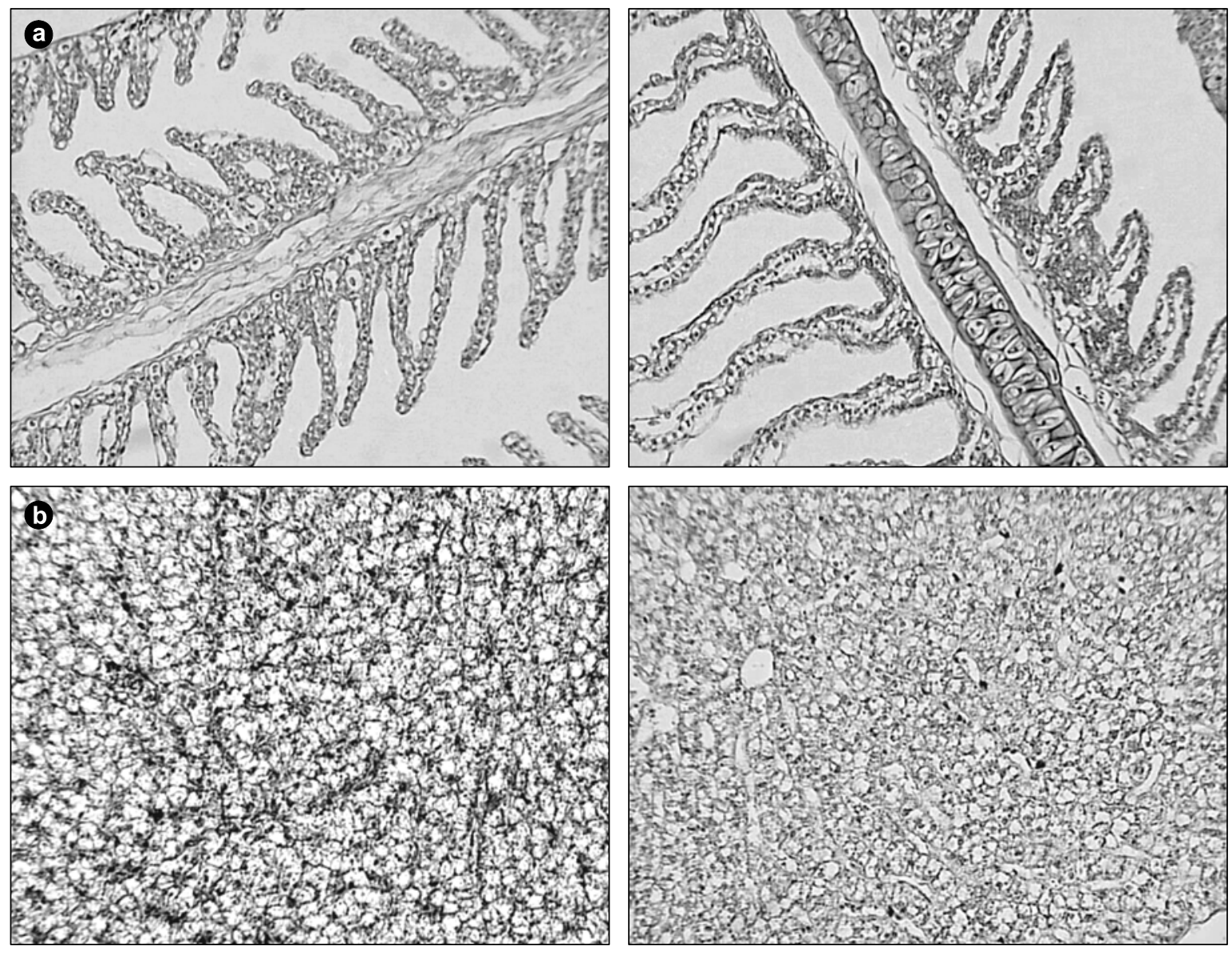

Figure 2. Histopathological alterations in Solea senegalensis after the period of exposure, in (a) gills (desquamation of secondary lamellar epithelial cells, hypertrophy and hyperplasia, blood extravasation in secondary lamellae, and shortening of secondary lamellae) and (b) liver (alteration and vacuolization of hepatocytes).

Figura 2. Alteraciones histopatológicas en Solea senegalensis después del periodo de exposición, en (a) branquias (descamación de células epiteliales de las laminillas secundarias, hipertrofia e hiperplasia, extravasación sanguínea en las laminillas secundarias y acortamientos de éstas) e (b) hígado (alteración y vacuolización de los hepatocitos).

Table 3. Pearson correlation matrix data showing the correlation between the PAHs measured and the exposure biomarkers analyzed. Tabla 3. Matriz de datos de la correlación de Pearson donde se muestra la correlación entre los PAHs medidos y los biomarcardores de exposición analizados.

\begin{tabular}{llllll}
\hline & & Total PAHs & EROD & GST & GR \\
\hline Total PAHs & Pearson correlation & & $0.883^{*}$ & $0.979^{* *}$ & $0.910^{*}$ \\
& Sig. (bilateral) & & 0.047 & 0.004 & 0.032 \\
\multirow{5}{*}{ EROD } & $N$ & 5 & 5 & 5 & 5 \\
& Pearson correlation & $0.83^{*}$ & & $0.910^{*}$ & $0.996^{* *}$ \\
& Sig. (bilateral) & 0.047 & & 0.032 & 0.000 \\
GST & $N$ & 5 & 5 & 5 & 5 \\
& Pearson correlation & $0.979^{* *}$ & $0.910^{*}$ & & $0.927^{*}$ \\
& Sig. (bilateral) & 0.004 & 0.032 & & 0.023 \\
GR & $N$ & 5 & 5 & 5 & 5 \\
& Pearson correlation & $0.910^{*}$ & $0.996^{* *}$ & $0.927^{*}$ & 5.023 \\
\end{tabular}

${ }^{*} P<0.05,{ }^{*} P<0.01$ 
organisms of a larger size, such as fish (Marigómez et al. 2006, Martínez-Gómez et al. 2006), which bioaccumulate in their tissues part of the pollutants found in fuel. Our results concur with those obtained in other similar bioassays also using fish and sediments from the affected area (Morales-Caselles et al. 2006a, 2007; Jiménez-Tenorio et al. 2007). They also coincide with other simulations made using sediment and fuel mixtures in the laboratory, which suggest the possible reversibility of the adverse effects observed on cells (exposure biomarkers), but show certain caution with respect to the recovery of tissue lesions, thus indicating the need for further studies with longer recuperation times (Salamanca et al. 2008).

\section{Acknowledgements}

This study is part of a research project financed by the Spanish Ministry of Education and Science (VEM2003-20563/ INTER and CTM2005-07282-C03-01/TECNO). The first author acknowledges receipt of a predoctoral scholarship from the CSIC $i 3$ p program.

English translation by Christine Harris.

\section{References}

Albaigés J, Bayona JM. 2003. La huella del fuel. In: Ensayos sobre el Prestige. Fundación Santiago Rey Fernández-LaTorre, Spain, pp. 80-103.

Bradford MB. 1976. A rapid and sensitive method for the quantification of microgram quantities of protein utilizing the principle of protein-dye binding. Anal. Biochem. 72: 248-254.

Cobelo-García A, Labandeira A, Prego R. 2005. Two opposite cases of metal accumulation in ria sediments: Ferrol and Corme-Laxe (Galicia, NW Iberian Peninsula). Cienc. Mar. 31: 653-659.

DelValls TA. 1999. La histopatología como componente de un método integrado para evaluación de la calidad ambiental en sistemas litorales. In: Sarasquete C, González de Canales ML, MuñozCueto JA (eds.), Patología, Fisiología y Biotoxicología en especies acuáticas. CSIC, Spain, pp. 77-91.

DelValls TA, Andrés A, Belzunce MJ, Buceta JL, Casado-Martínez MC, Castro R, Riba I, Viguri JR, Blasco J. 2004. Chemical and ecotoxicological guidelines for managing disposal of dredged material. Trends Anal. Chem. 23: 819-828.

Evangelista AJA, Nascimiento IA, Pereira SA, Lopes MBNL, Martins LKP, Fillman G. 2005. Assessing the potential toxicity of marine sediments found in petroleum industry areas: A new approach based on responses of postlarval shrimp. Cienc. Mar. 31: 43-55.

Fernández N, Cesar A, González M, DelValls TA. 2006a. Nivel de contaminación de sedimentos afectados por el vertido del Prestige y sus efectos sobre el desarrollo embrionario del erizo de mar. Cienc. Mar. 32: 421-427.

Fernández N, Cesar A, Salamanca MJ, DelValls TA. 2006b. Toxicological characterisation of the aqueous soluble phase of the Prestige fuel-oil using the sea-urchin embryo bioassay. Ecotoxicology 15: 593-599.

Gagné F, Blaise C. 1993. Hepatic metallothionein level and mixed function oxidase activity in fingerling rainbow trout (Oncorhynchus mykiss) after acute exposure to pulp and paper mill effluents. Water Res. 27: 1669-1682. concentraciones de PAHs produce daños en los organismos expuestos, que además bioacumulan en sus tejidos estos contaminantes (Laffon et al. 2006, Soriano-Sanz et al. 2006).

En cuanto a la histopatología, los índices de lesión calculados no fueron tan altos como los observados en otros trabajos que utilizan peces para evaluar sedimentos naturales (JiménezTenorio et al. 2007, Morales-Caselles et al. 2007), debido a que gran parte de la mortandad se produjo por contacto directo del fuel con las branquias de los peces y no por las lesiones. No obstante, se han observado alteraciones en el hígado similares a las encontradas en estudios realizados con individuos de diferentes especies de peces muestreados en la zona afectada por el vertido del Prestige (Marigómez et al. 2006).

La actividad enzimática evaluada en $S$. senegalensis presentó un incremento significativo respecto a los controles. Se han observado aumentos en la actividad de estas tres enzimas al exponer distintas especies de peces, crustáceos y bivalvos a PAHs y PCBs (Van de Oost et al. 2003, Martín-Díaz 2004). Martínez-Gómez et al. (2006) obtuvieron resultados similares con los peces Lepidorhombus boscii y Callionymus lyra.

Este estudio confirma el carácter tóxico del fuel vertido por el Prestige, lo cual queda comprobado con los efectos adversos demostrados aquí mediante los biomarcadores de exposición y las alteraciones histopatológicas en $S$. senegalensis. Se demuestra así que concentraciones altas de hidrocarburos no sólo afectan a organismos de tamaño pequeño, como los anfípodos (Morales-Caselles et al. 2006b), o al éxito de la embriogénesis de distintos organismos acuáticos como equinodermos (Fernández et al. 2006a, b) y bivalvos (Mariño-Balsa et al. 2003), sino que también producen efectos negativos en organismos de mayor tamaño como los peces (Marigómez et al. 2006, Martínez-Gómez et al. 2006), quienes además bioacumulan en sus tejidos parte de los contaminantes presentes en el fuel. Los resultados obtenidos en este trabajo son consistentes con los resultados de bioensayos similares con sedimentos procedentes de la zona impactada (Morales-Caselles et al. 2006a, 2007; Jiménez-Tenorio et al. 2007) utilizando también peces, y con otras simulaciones realizadas con mezclas de sedimento y fuel en laboratorio, sugiriendo también la posible reversibilidad de los efectos adversos observados a nivel celular (biomarcadores de exposición). No obstante, existe más reserva respecto a la reparación de las lesiones en tejidos, por lo que se proponen estudios con periodos de recuperación mayores (Salamanca et al. en prensa).

\section{Agradecimientos}

Este trabajo se realizó dentro del proyecto de investigación financiado por el Ministerio de Educación y Ciencia de España VEM2003-20563/INTER y CTM2005-07282-C03$01 /$ TECNO. La primera autora agradece al programa i3p del CSIC su beca predoctoral. 
George SG. 1994. Enzymology and molecular biology of phase II xenobiotic-conjugating enzymes in fish. In: Malins DC, Ostrander GK (eds.), Aquatic Toxicology, Molecular, Biochemical and Cellular perspectives. Lewis Publishers, CRC press, pp. 37-85.

Gutiérrez M. 1967. Coloración histológica para ovarios de peces, crustáceos y moluscos. Inv. Pesq. 31: 265-271.

Jiménez-Tenorio N, Morales-Caselles C, Kalman J, Salamanca MJ, González de Canales ML, Sarasquete C, DelValls TA. 2007. Determining sediment quality for regulatory proposes using fish chronic bioassays. Environ. Int. 33: 474-480.

Keith LH, Telliard WA. 1979. Priority pollutants. I-A perspective view. Environ. Sci. Technol. 13: 416-423.

Laffon B, Aldao I, Pérez-Cadahíz B, Pásaro E, Méndez J. 2006. First step in the evaluation of the effects of Prestige oil on the shore environment: Availability, bioaccumulation and DNA damage. Cienc. Mar. 32: 389-399.

Lafontaine Y, Gagné F, Blaise C, Costan G, Gagnon P, Chan HM. 2000. Biomarkers in zebra mussels (Dreissena polymorpha) for the assessment and monitoring of water quality of the St. Lawrence River (Canada). Aquat. Toxicol. 50: 51-70.

Loring DH, Rantala RTT. 1992. Methods for the geochemical analyses of marine sediments and suspended particulate matter. Earth-Sci. Rev. 32: 235-283.

Marigómez I, Soto M, Cancio I, Orbea A, Garmendia L, Cajaraville M. 2006. Cell and tissue biomarkers in mussel, and histopathology in hake and anchovy from Bay of Biscay after the Prestige oil spill (Monitoring Campaign 2003) Mar. Pollut. Bull. 53: 287-304.

Mariño-Balsa JC, Pérez P, Estévez-Blanco P, Saco-Álvarez L, Fernández E, Beira R. 2003. Evaluación de la toxicidad de sedimento y agua de mar contaminados por el vertido de fuel del Prestige, mediante el uso de bioensayos con las almejas Venerupis pullastra, Tappes decussatus y Venerupis rhomboideus y la microalga Skeletonema costatum. Cienc. Mar. 29: 115-122.

Martín-Díaz ML. 2004. Determinación de la calidad ambiental de sistemas litorales y de estuario de la Península Ibérica utilizando ensayos de campo y de laboratorio. Ph.D. thesis, Universidad de Cádiz, pp. 153-177.

Martín-Díaz ML, Blasco J, De Canales ML, Sales D, DelValls TA. 2004a. Bioaccumulation and toxicokinetics of dissolved heavy metals from the Guadalquivir Estuary after the Aznalcóllar mining spill using Ruditapes philippinarum. Arch. Environ. Contam. Toxicol. 48: 233-241.

Martín-Díaz ML, Villena-Lincoln A, Bamber S, Blasco J, DelValls TA. 2004b. An integrated approach of biomarker responses using Carcinus maenas: Simulation of the Aznalcóllar mining spill. Chemosphere 58: 615-626.

Martín-Díaz ML, Tuberty SR, McKenney CL, Sales D, DelValls TA. 2005. Effects of cadmium and zinc on Procambarus clarkii: Simulation of the Aznalcóllar mining spill. Cienc. Mar. 31: 197-202.

Martínez-Gómez C, Campillo JA, Benedicto J, Fernández B, Valdés J, García I, Sánchez F. 2006. An assessment of the biological effects related to the Prestige oil spill applying biomarkers in demersal fish (Lepidorhombus boscii and Callionymus lyra) from the northem Iberian shelf. Mar. Pollut. Bull. 53: 305-314.

Morales-Caselles C, Jiménez-Tenorio N, González de Canales ML, Sarasquete C, DelValls TA. 2006a. Ecotoxicity of sediments contaminated by the oil spill associated with the tanker Prestige using juveniles of the fish Sparus aurata. Arch. Environ. Contam. Toxicol. 51: 652-660.

Morales-Caselles C, Kalman J, Riba I, DelValls TA. 2006b. Comparing sediment quality in Spanish littoral areas affected by acute (Prestige, 2002) and chronic (Bay of Algeciras) oil spills. Environ. Pollut. 146: 233-240.

Morales-Caselles C, Jiménez-Tenorio N, Riba I, DelValls TA. 2007. Kinetic of biomarker responses in juveniles of the fish Sparus aurata exposed to contaminated sediments. Environ. Monit. Assess. 131:

211-20.

Pelletier MC, Burgess RM, Ho KT, Khun A, McKinney RA, Ryba SA. 1997. Phototoxicity of individual polycyclic aromatic hydrocarbons and petroleum to marine invertebrate larvae and juveniles. Environ. Toxicol. Chem. 16: 2190-2199.

Pelletier MC, Burgess RM, Cantwell MG, Serbst JR, Ho KT, Ryba SA. 2000. Importance of material transfer of the photoreactive polycyclic aromatic hydrocarbon fluoranthene from benthic adult bivalves to their pelagic larvae. Environ. Toxicol. Chem. 19: 2691-2698.

Reynolds WJ, Feist SW, Jones GJ, Lyons BP, Sheahan DA, Stentiford GD. 2003. Comparison of biomarker and pathological responses in flounder (Platichthys flesus L.) induced by ingested polycyclic aromatic hydrocarbon (PAH) contamination. Chemosphere 52: $1135-1145$.

Riba I, Casado-Martínez MC, Forja JM, DelValls TA. 2004. Sediment quality on the Atlantic coast of Spain. Environ. Toxicol. Chem. 23: 271-282.

Riba I, Blasco J, Jiménez-Tenorio N, González de Canales ML, DelValls TA. 2005. Heavy metal bioavailability and effects. II. Histopathology-bioaccumulation relationships caused by mining activities in the Gulf of Cádiz (SW Spain). Chemosphere. 58: 671-682.

Salamanca MJ, Jiménez-Tenorio N, F-Reguera D, Morales-Caselles C, DelValls TA. An early approach for the evaluation of repair processes in fish after exposure to sediment contaminated by an oil spill. J. Environ. Sci. Heal. A. A43(14).

Soriano-Sanz JA, Franco-Hernández A, Viñas-Diéguez L, CambeiroCambeiro B, González-Fernández JJ. 2006. Preliminary data on polycyclic aromatic hydrocarbons (PAHs) in wild mussels from the Cantabrian coast (N Spain) following the Prestige oil spill. Cienc. Mar. 32: 457-463.

Van der Oost R, Beyer J, Vermeulen NPE. 2003. Fish bioaccumulation and biomarkers in environmental risk assessment. Environ. Toxicol. Pharmacol. 13: 57-149.

Winston GW, DiGiulio RT. 1991. Prooxidant and antioxidant mechanisms in aquatic organisms. Aquat. Toxicol. 19: 137-161.

Recibido en febrero de 2008;
aceptado en junio de 2008. 